\title{
PERTANGGUNGJAWABAN PIDANA TERHADAP PELAKU PEMBAKARAN HUTAN DI PROVINSI JAMBI
}

\author{
Oleh: \\ Ferdricka Nggeboe* \\ Reza Iswanto * \\ Sriayu Indah Puspita*
}

\begin{abstract}
Abstrak
Pembakaran hutan di Provinsi Jambi dari tahun ke tahun terus mengalami peningkatan sehingga mengakibatkan kabut asap yang begitu tebal yang menyelimuti Provinsi Jambi. Oleh karena itu, selain akibat dari kebakaran hutan tersebut yaitu mengakibatkan kabut asap yang tebal, kebakaran hutan juga mengakibatkan berbagai macam makhluk hidup seperti tumbuhan dan hewan mengalami kepunahan sehingga terhadap pelaku kebakaran hutan tersebut harus dipertanggungjawabkan secara pidana mengingat bahaya yang ditimbulkannya begitu besar. Namun, walaupun telah banyak menimbulkan kerugian terhadap masyarakat Provinsi Jambi, tetapi belum ada satu perusahaan yang dijatuhkan sanksi pidana, hanya berupa penyegelan terhadap perusahaan. Selain itu juga, faktor yang mempengaruhi terwujudnya pertanggungjawaban pidana pelaku pembakaran hutan di Provinsi Jambi adalah belum ada ketegasan dari pemerintah Provinsi Jambi maupun aparat penegak hukum untuk menjatuhkan sanksi pidana, bahkan pemerintah Provinsi Jambi dan penegak hukum masih belum dapat membuktikan kesalahan para pelaku pembakaran hutan dan lahan. Untuk itu, upaya yang akan datang terkait dengan pertanggungjawaban pidana terhadap pelaku pembakaran hutan di Provinsi Jambi adalah pemerintah Provinsi Jambi maupun aparat penegak hukum harus bertindak tegas terhadap pelaku pembakaran hutan berupa penjatuhkan sanksi pidana, dan juga berupaya melakukan penyuluhan hukum sekaligus melibatkan masyarakat setempat untuk pelaporan terkait dengan ada pelaku pembakaran hutan agar mendapatkan sanksi pidana sebagaimana dalam Undang-Undang Nomor 32 Tahun 2009 Tentang Perlindungan Dan Pengelolaan Lingkungan Hidup.
\end{abstract}

Kata Kunci :Pertanggungjawaban Pidana, Pelaku, Pembakaran Hutan

\section{A. Pendahuluan}

Hutan merupakan paru-paru dunia yang harus dilindungi karena keberadaan hutan sangat berperan penting dalam kehidupan manusia. Namun, akhir-akhir ini banyak sekali perusahaan-perusahaan yang membuka hutan dengan tujuan untuk melakukan aktivitas perusahaan dengan cara melakukan pembakaran hutan. Dengan terjadinya pembakaran hutan yang dilakukan oleh perusahaan-perusahaan tersebut maka mengakibatkan timbulnya kabut asap. Oleh karena itu, akhir-akhir ini tidak mengherankan kabut asap tebal yang terjadi di Provinsi Jambi dikarenakan akibat dari adanya kebakaran hutan yang cukup luas. Hal demikian dapat dilihat berdasarkan hasil analisis Citra Satelit Lansat TM 8 oleh Komunitas

\footnotetext{
* Pengajar Program Magister Ilmu Hukum UNBARI

${ }^{*}$ Pengajar Fakultas Hukum UNBARI

* Pengajar Fakultas Hukum UNBARI
} 
Konservasi Indonesia (KKI) Warsi, hingga Ahad, 22 September 2019 tercatat 47.510 hektare lebih kawasan hutan di Jambi yang terbakar. ${ }^{1}$

Tidak hanya seluas 47.510 hektare saja kebakaran hutan yang terjadi di Provinsi Jambi, dampak lain juga dialami oleh masyarakat Provinsi Jambi terkait dengan adanya kebakaran hutan di Provinsi Jambi, antara lain yaitu terhalangnya pandangan atau jarak pandang yang pendek yang dialami oleh masyarakat Provinsi Jambi baik terhadap pengendara kendaraan di jalan raya maupun masyarakat Provinsi Jambi yang ada di dalam rumah, kondisi ini pun menimbulkan bahaya sangat besar terhadap masyarakat Provinsi Jambi. Tidak hanya itu saja, kabut asap yang dihasilkan dari kebakaran hutan ini juga mengganggu pernapasan masyarakat Provinsi Jambi terutama anak-anak, sehingga anak-anak harus diliburkan dari sekolahnya untuk beberapa waktu, sesuai dengan kondisi ketebalan kabut asap yang terjadi

Selain itu juga akibat kabut asap yang terjadi, membuat jarak pandang yang hanya mencapai 500 meter menyebabkan ada bandara Sultan Taha Jambi terpaksa ditutup untuk beberapawaktudantidakmelayanipenerbangan. Keadaan jarak pandang 500 meteradalah jauh dari batas minimal jarak pandang penerbangan yakni 3.500 meter. Ada empat bandara yang ditutupkarenakabutasaptebal antara lain Bandara Kalimantan Berau (Kalimantan Timur), Bandara Juwata Tarakan (Kalimantan Utara), Bandara APT Pranoto Samarinda (Kalimantan Timur), dan Bandara Syamsudin Noor Banjarbaru (Kalimantan Selatan). ${ }^{2}$ Oleh karena itu, sudah seharusnya terkait dengan kasus kebakaran hutan ini Pemerintah Provinsi Jambi harus bertindak lebih tegas terhadap pelaku pembakaran hutan dan lahan baik oknum dari perusahaan maupun orang perorangan masyarakat yang melakukan pembakaran hutan di Provinsi Jambi, denganharapan kedepannya tidak terjadi lagi hal yang serupa di Provinsi Jambi yaitu kebakaran hutan yang membakar luas lahan dan mengakibatkan banyak korban.

Untuk menjerat oknum yang melakukan pembakaran hutan baik oknum yang berasal dari perusahaan maupun orang perorangan maka harus ada aturan hukum yang mengaturnya terlebih dahulu, dan senyatanya peraturan yang mengatur tentang kehutanan sudah ada yaitu Undang-Undang No.18 Tahun 2013.Tentang Larangan Pembakaran Hutan dan Lahan, namun sayangnya dalam undang-undang tersebut tidak ada satupun rumusan pasal-pasalnya yang memberikan ketentuan hukuman atau sanksi terhadap pelaku pembakaran hutan dan lahan .Akibatnya undang-undang ini tidak dapat menjerat pelaku yang melakukan pembakaran

1 https://www.teras.id/news/pat-2/184969/kebakaran-hutan-dan-lahan-di-jambi-kian-meluas, diakses tanggal 29 September 2019.

${ }^{2}$ https://www.dw.com/id/gugatan-pidana-bagi-pelaku-pembakaran-hutan/a-50443840, diakses tanggal 29 September 2019. 
hutan dan lahan, dengan kata lain dalam undang-undang ini tidak ada tindak pidana pembakaran hutan dan lahan, begitupun sulitnya pembuktian pelaku pembakaran hutan dan lahan juga termasuk hal-hal yang menyebabkan tidak tegaknya sanksi terhadap pelaku. Jika kita bercermin pada asas hokum pidana kita maka sesuai dengan asas legalitas yang tercantum dalam Pasal 1 Kitab Undang-Undang Hukum Pidana, yang menyebutkan :

1. Suatu perbuatan tidak dapat dipidana, kecuali berdasarkan kekuatan ketentuan perundang-undangan pidana yang telah ada.

2. Bilamana ada perubahan dalam perundang-undangan sesudah perbuatan dilakukan, maka terhadap terdakwa diterapkan ketentuan yang paling menguntungkannya.

Dengan demikian, sudah jelas bahwa harus ada dibuat terlebih dahulu rumusan aturan hukum yang mengatur terkait tindak pidana pembakaran hutan dan lahan baru kemudian pelaku perbuatan pembakaran hutan itu dapat dijatuhkan hukuman pidana, Apabila belum ada pengaturan terkait dengan tindak pidana pembakaran hutan maka pelaku pembakaran hutan tersebut akan dikenakan sanksi pidana yang sesuai dengan perbuatan pelaku tersebut.

Namun, pada kenyataannya terkait dengan tindak pidana pembakaran hutan yang saat ini terjadi di Provinsi Jambi maka para penegak hokum telah ada aturan hukum pidana yang mengatur perbuatan tersebut. Yaitu Aturan hukum pidana yang mengatur tentang tindak pidana pembakaran hutan tersebut sebagaimana telah termuat di dalam Undang-Undang Nomor 32 Tahun 2009 Tentang Perlindungan Dan Pengelolaan Lingkungan Hidup.

Tujuan diadakannya Undang-Undang Nomor 32 Tahun 2009 Tentang Perlindungan Dan Pengelolaan Lingkungan Hidup ini untuk menentukan perbuatan apa saja yang diperbolehkan dan dilarang oleh masyarakat, orang perorangan maupun korporasi dalam mengolah hutan dan lahan, sebagaimana judulnya adalah perlindungan dan pengelolaan lingkungan hidup. Perbedaan tujuan yang jelas sebagaimana Undang-Undang No 18 tahun 2013 yang jelas menyebutkan tujuan tentang larangan pembakaran hutan dan lahan. Hal yang senada juga diutarakan oleh Moeljatno, dimana Moeljatno merumuskan hukum pidana sebagai bagian dari pada keseluruhan hukum yang berlaku di suatu negara yang mengadakan dasar-dasar dan aturan-aturan, untuk menentukan : ${ }^{3}$

\footnotetext{
${ }^{3}$ Roni Wiyanto, Asas-Asas Hukum Pidana Indonesia, Cetakan Pertama, Bandung: CV. Mandar Maju, 2012, hal 7 .
} 
1. Perbuatan-perbuatan mana yang tidak boleh dilakukan, yang dilarang, dengan disertai ancaman atau sanksi yang berupa pidana tertentu bagi barang siapa melanggar larangan tersebut.

2. Kapan dan dalam hal-hal apa kepada mereka yang telah melanggar laranganlarangan itu dapat dikenakan atau dijatuhi pidana sebagaimana yang telah diancamkan.

3. Dengan cara bagaimana pengenaan pidana itu dapat dilaksanakan apabila ada orang yang disangka telah melanggar larangan tersebut.

Untuk itu, sudah jelas bahwa diadakannya Undang-Undang Nomor 32 Tahun 2009 Tentang Perlindungan Dan Pengelolaan Lingkungan Hidup tersebut untuk menentukan perbuatan-perbuatan yang mana dikategorikan sebagai tindak pidana pembakaran hutan dan lahan, kemudian apabila oknum tersebut telah termasuk ke dalam perbuatan yang dikategorikan sebagai tindak pidana pembakaran hutan dan lahan, barulah oknum tersebut dapat disangka akan melakukan perbuatan pidana dan setelah cukup minimal dua alat bukti barulah perkara pelaku pelakukan pengrusakan hutan dapat diteruskan proses peradilan pidana untuk mendapatkan putusan pengadilan dan terhadap terdakwa yang telah melakukan tindak pidana pembakaran hutan tersebut maka terdakwa tersebut akan dikenakan sanksi pidana sesuai denganrumusan pasal yang tercantum di dalam Undang-Undang Nomor 32 Tahun 2009 Tentang Perlindungan Dan Pengelolaan Lingkungan Hidup.

Sebenarnya sanksi pidana yang dijatuhkan terhadap oknum yang melakukan pembakaran hutan di Provinsi Jambi sudah sesuai dengan perbuatan yang dilakukan oleh oknum tersebut sehingga sudah seharusnya baik dari pemerintah Provinsi Jambi maupun penegak hukum menggunakan hukum pidana untuk menjerat pelaku yang menjadi oknum pembakaran hutan di Provinsi Jambi tersebut. Hal yang demikian juga diutarakan oleh Djisman Samosir bahwa pidana harus sebanding dengan kesalahan, karenanya pelanggaran ringan tidak boleh dipidana lebih berat daripada pelanggaran berat. ${ }^{4}$

Oleh karena itu, terkait dengan tindak pidana pembakaran hutan yang telah merugikan banyak orang termasuk masyarakat di Provinsi Jambi maka sudah seharusnya terhadap oknum baik dari perusahaan maupun orang perorangan harus dijerat sanksi sesuai dengan isi rumusan Pasal 108 Undang-Undang Nomor 32 Tahun 2009 Tentang Perlindungan Dan Pengelolaan Lingkungan Hidup karena merupakan pertanggungjawaban atas perbuatan hal 154 .

\footnotetext{
${ }^{4}$ C. Djisman Samosir, Penologi Dan Pemasyarakatan, Cetakan Pertama, Bandung: Nuansa Aulia, 2016,
} 
yang dilakukannya dengan membakar hutan di wilayah Provinsi Jambi. Adapun isi dari Pasal 108 Undang-Undang Nomor 32 Tahun 2009 Tentang Perlindungan Dan Pengelolaan Lingkungan Hidup tersebut yaitu setiap orang yang melakukan pembakaran lahan sebagaimana dimaksud dalam Pasal 69 ayat (1) huruf h dipidana dengan pidana penjara paling singkat 3 (tiga) tahun dan paling lama 10 (sepuluh) tahun dan denda paling sedikit Rp. 3.000.000.000,00 (tiga miliar rupiah) dan paling banyak Rp. 10.000.000.000,00 (sepuluh miliar rupiah). Dengan demikian, apabila dilihat dari penjatuhan sanksi pidana yang tercantum di dalam Pasal 108 Undang-Undang Nomor 32 Tahun 2009 Tentang Perlindungan Dan Pengelolaan Lingkungan Hidup tersebut maka sudah seharusnya dapat menjerat perbuatan yang dilakukan oleh pelaku tindak pidana pembakaran hutan di Provinsi Jambi.

Namun, pada kenyataannya menurut Kepala Kampanye Hutan Global Greenpeace Indonesia, Kiki Taufik, menyebutkan bahwa pemerintah tidak serius dalam hal penegakan hukum dan menjadi alasan utama mengapa kebakaran hutan dan lahan (karhutla) kembali terjadi setiap tahun. Perusahaan-perusahaan yang melakukan pembakaran hutan dan lahan sejak dari tahun 2015 sampai 2018di Provinsi Jambi, tapi tidak ada satupun yang mendapat sanksi, baik sanksi administratif atau sanksi perdata..$^{5}$ Tentunya apalagi sanksi pidana, sedangkan di tahun 2019 hanya satu perusahaan yang dikenakan sanksi pidana. Jika dilihat kejadian pada tahun 2015 sampai 2018 tentunya sangat menyedihkan karena urusan perusahaan yang telah melakukan pembakaran hutan tersebut lolos begitu saja dari sanksi administratif maupun sanksi perdata. Hal yang demikian sangat mengecewakan karena jangankan menggunakan sanksi hukum pidana, sanksi administrasi dan perdata juga tidak dijerat terhadap pelaku pembakaran hutan baik itu perusahaan maupun orang perorangan.

Dengan demikian, berdasarkan uraian yang telah dipaparkan di atas, maka penulis akan membatasi permasalahan yang akan di bahas di dalam makalah ini. Adapun pertanyaan terkait dengan permasalahan di atas adalah :

1. Bagaimana pertanggungjawaban pidana terhadap pelaku pembakaran hutan di Provinsi Jambi ?

2. Apa faktor yang mempengaruhi terwujudnya pertanggungjawaban pidana pelaku pembakaran hutan di Provinsi Jambi ?

3. Bagaimana upaya yang akan dilakukan sehubungan dengan pertanggung jawaban pidana terhadap pelaku pembakaran hutan di Provinsi Jambi?

\footnotetext{
${ }^{5}$ https://www.bbc.com/indonesia/indonesia-49806272, diakses tanggal 29 September 2019.
} 


\section{B. Pertanggungjawaban Pidana Terhadap Pelaku Pembakaran Hutan Di Provinsi Jambi}

Setiap subyek hukum tentu tidak lepas dari pertanggungjawaban karena setiap subyek hukum pasti melakukan kesalahan dan atas kesalahan tersebut maka subyek hukum tersebut harus menanggung perbuatan yang sesuai dengan kesalahan yang dilakukan oleh subyek hukum itu sendiri. Hal yang demikian dapat dibenarkan karena subyek hukum merupakan pembawa hak dan kewajiban. Jadi, apabila subyek hukum melakukan suatu kesalahan maka subyek hukum tersebut harus mempertanggungjawabkan atas perbuatan yang dilakukannya. Hal yang sama juga dikemukakan oleh Mertokusumo, menurutnya subyek hukum adalah segala sesuatu yang dapat memperoleh hak dan kewajiban dari hukum. Hanya manusia yang dapat menjadi subyek hukum. ${ }^{6}$

Dengan demikian, dapat dikatakan bahwa setiap subyek hukum dalam melakukan suatu perbuatan harus mempertanggungjawabkan atas perbuatannya, baik perbuatan yang diperbolehkan oleh undang-undang (aturan hukum) maupun perbuatan yang dilarang oleh undang-undang (aturan hukum). Oleh karena itu, apabila di dalam melakukan suatu perbuatan hukum terdapat kesalahan maka atas kesalahan tersebut subyek hukum harus mempertanggungjawabkannya baik secara administrasi, perdata maupun pidana tergantung dari kesalahan yang dilakukan oleh subyek hukum itu sendiri.

Akan tetapi, subjek hukum tidak hanya tertuju kepada manusia saja, melainkan juga subjek hukum ditujukan kepada badan hukum karena di dalam badan hukum ada manusia yang harus mempertanggungjawabkan atas perbuatan yang dilakukan oleh badan hukum tersebut. Hal yang demikian juga dijelaskan oleh H. Zaeni Asyhadie dan Arief Rahman bahwa menurut hukum ada dua subjek hukum yaitu pertama manusia (person), di dalam hukum, perkataan seseorang atau orang (person) berarti pembawa hak dan kewajiban. Berlakunya seseorang sebagai pembawa hak, mulai dari dia dilahirkan sampai dia meninggal dunia. Kedua badan hukum (recht persoon), selain orang (person) badan atau perkumpulan dapat juga memiliki hak dan dapat melakukan perbuatan hukum seperti halnya manusia. Badan atau perkumpulan itu memiliki harta kekayaan sendiri, ikut serta dalam persoalan hukum dan dapat juga digugat atau menggugat di pengadilan dengan perantaraan pengurusnya, badan yang demikian disebut badan hukum (recht persoon). Perkumpulan sebagai badan hukum tentu tidaklah semua jenis perkumpulan, perkumpulan yang dapat

\footnotetext{
${ }^{6}$ Harumiati Natadimaja, Hukum Perdata Mengenai Hukum Orang Dan Hukum Benda, Cetakan Kedua, Yogyakarta: Graha Ilmu, 2009, hal 7.
} 
dinamakan badan hukum apabila perkumpulan tersebut diciptakan sesuai ketentuan yang berlaku (hukum). ${ }^{7}$ Jadi, dalam hal badan hukum ini yang harus mempertanggungjawabkan atas kesalahan yang dilakukan oleh badan hukum tersebut adalah orang yang memegang badan hukum itu sendiri seperti manager atau direktur di dalam badan hukum tersebut.

Dalam hal pertanggungjawaban pidana, untuk dapat menentukan tersangka atau pelaku tersebut dipertanggungjawabkan kata suatu tindak pidana harus memilih unsur-unsur yang terkandung di dalam suatu aturan hukum atau undang-undang. Jika tidak terdapat unsurunsur yang ada di aturan hukum atau undang-undang tersebut maka perbuatan yang dilakukan oleh tersangka atau pelaku tersebut tidak dapat dipertanggungjawabkan secara pidana.

Dalam hal pertanggungjawaban pidana biasanya dibagi menjadi dua yaitu pertanggungjawaban pengganti (vicarious liability) dan pertanggungjawaban ketat (strict liability). Menurut doktrin atau ajaran strict liability, pertanggungjawaban pidana dapat dibebankan kepada pelaku tindak pidana yang bersangkutan dengan tidak perlu dibuktikan adanya kesalahan pada pelakunya. ${ }^{8}$ Dengan demikian, apabila perilaku tersebut telah memiliki niat untuk melakukan suatu kejahatan walaupun belum ada perbuatan yang terwujud atasnya tersebut, akan tetapi niat dari pelaku tersebut sudah termasuk pertanggungjawaban ketat (strict liability). Oleh karena itu, apabila pelaku pembakaran hutan tersebut setelah memiliki niat dan ingin melakukan niat tersebut, namun ketika melakukan aksinya diketahui oleh orang lain maka pelaku tersebut dapat dikenakan pertanggungjawaban ketat (strict liability). Biasanya pertanggungjawaban ketat (strict liability) ini digunakan terhadap pelaku yang hanya melakukan tindak pidana secara sendiri-sendiri.

Sedangkan model yang vicarious liability menurun Maxim, seseorang yang berbuat melalui orang lain, dianggap dia sendiri yang melakukan perbuatan itu, contohnya adalah seorang orang pemberi kuasa bertanggung jawab atas perbuatan yang dilakukan oleh agen atau penerima kuasa sebagai perbuatan itu dilakukan dalam lingkungan kewenangannya. ${ }^{9}$ Dengan demikian, yang terlibat di dalam pertanggungjawaban pengganti atau vicarious liability adalah seorang yang atasan yang tidak melakukan sesuatu kesalahan, akan tetapi kesalahan tersebut dilakukan oleh bahannya maka atasan tersebut harus bertanggung jawab atas perbuatan atau kesalahan yang dilakukan oleh bawahan sehingga atasan tersebut dapat dijelaskan dengan sanksi pidana juga.

\footnotetext{
${ }^{7}$ H. Zaeni Asyhadie dan Arief Rahman, Pengantar Ilmu Hukum, Cetakan Kedua, Jakarta: Raja Grafindo Persada, 2013, hal 61.

${ }^{8}$ Suhandi Cahaya, Kejahatan korporasi, Cetakan Pertama, Jakarta: Law Office, 2013, hal 80.

${ }^{9}$ Ibid, hal 88 .
} 
Dalam hal kebakaran hutan dan lahan, apabila dikaitkan dengan pertanggungjawaban pengganti atau vicarious liability maka direktur atau manager harus bertanggung jawab atas kebakaran hutan yang dilakukan oleh perusahaannya baik itu dilakukan oleh bawahannya maupun perintah dari dirinya sendiri. Dengan adanya pertanggungjawaban pengganti atau vicarious liability ini sebuah perusahaan tidak bisa lagi menyangkal atas kesalahan yang dilakukan oleh perusahaan tersebut maupun bawahannya sertapihak perusahaan juga dapat dijatuhkan berbagai macam sanksi baik berupa sanksi administrasi, sanksi perdata maupun sanksi pidana.

Pada kenyataannya menurut Kepala Kampanye Hutan Global Greenpeace Indonesia, Kiki Taufik, menyebutkan bahwa pemerintah tidak serius dalam hal penegakan hukum dan menjadi alasan utama mengapa karhutla kembali terjadi setiap tahun. Perusahaan-perusahaan yang dari 2015 sampai 2018 lokasinya terbakar, tapi tidak ada satupun yang mendapat sanksi, baik sanksi administratif atau sanksi perdata. ${ }^{10}$

Sementara itu, Polda Jambi sendiri sampai saat ini baru memeriksa 4 perusahaan yang konsesinya terbakar di tahun 2019 ini. Dari 4 perusahaan yang mengalami kebakaran di lokasinya tersebut adalah, PT. Mega Anugrah Sawit (MAS) yang ada di Kabupaten Muaro Jambi, PT. Alam Bukit Tiga Puluh (ABT) berada di Kabupaten Tebo, PT. REKI yang berada di Kabupaten Batanghari dan PT. Wira Karya Sakti (WKS/Sinar Mas Group) yang berada di Kabupaten Tanjung Jabung Barat. ${ }^{11}$ Kemudian berdasarkan daftar perusahaan yang telah disegel hingga 4 September 2019 akibat kebakaran hutan dan lahan, PT ABT merupakan salah satu dari 42 konsesi yang telah disegel oleh Menteri Lingkungan Hidup dan Kehutanan $($ KLHK $){ }^{12}$

Dari data yang telah dijelaskan di atas maka dapat disimpulkan bahwa sanksi yang dijatuhkan terhadap perusahaan yang melakukan pembakaran hutan hanya berupa penyegelan di salah satu perusahaan yang ada di provinsi Jambi yaitu PT. Alam Bukit Tiga Puluh (ABT), sedangkan 3 perusahaan lainnya masih dalam proses penanganan di Polda Jambi. Apabila dikaitkan dengan konsep pertanggungjawaban pidana maka PT. Alam Bukit Tiga Puluh (ABT) belum dijatuhkan sanksi pidana, hanya berupa penyegelan terhadap perusahaan tersebut. Dengan demikian, pertanggungjawaban pidana terhadap perusahaan yang melakukan

\footnotetext{
${ }^{10}$ https://www.bbc.com/indonesia/indonesia-49806272, diakses tanggal 29 September 2019. ${ }^{11}$ https://jamberita.com/read/2019/09/17/5953086/aliansi-peduli-karhutla-dan-kabut-asap-jambidesak-sanksi-perusahaan-wilayah-konsensinya-terbakar, diakses tanggal 29 September 2019.

${ }^{12} \mathrm{https} / / /$ mediaindonesia.com/read/detail/259455-penegakan-hukum-pada-perusahaan-pembakar-lahantelah-diterapkan, diakses tanggal 29 September 2019.
} 
pembakaran hutan masih belum dilakukan terhadap perusahaan tersebut dan dan penegakan hukum juga masih belum tegas di dalam menegakkan hukum terhadap perusahaan yang melakukan pembakaran hutan di Provinsi Jambi.

Hal yang demikian sangat disayangkan karena akibat dari kebakaran hutan tersebut Banyak masyarakat Provinsi Jambi yang tidak dapat melakukan aktivitas seperti biasa dan anak-anak sekolah juga sempat diliburkan untuk sementara mengingat bahayanya kabut asap yang mengancam pernapasan anak-anak. Oleh karena itu, perlu adanya ketegasan dari penegak hukum untuk menjatuhkan sanksi pidana terhadap perusahaan yang melakukan pembakaran hutan di Provinsi Jambi karena penjatuhan sanksi tersebut merupakan pertanggungjawaban atas perbuatan yang dilakukan oleh perusahaan tersebut dan sekaligus akan terlihat bukti keseriusan pemerintah dan aparat penegak hukum untuk dapat menjerat pelaku yang melakukan pembakaran hutan di Provinsi Jambi.

\section{Faktor Yang Mempengaruhi Terwujudnya Pertanggungjawaban Pidana Pelaku Pembakaran Hutan Di Provinsi Jambi}

Di dalam menjerat pelaku pembakaran hutan baik terhadap korporasi atau perusahaan maupun orang perorangan sulit untuk dipertanggungjawabkan karena dari sisi pemerintahan Provinsi Jambi saja kurang serius dalam menanggapi pembakaran hutan yang dilakukan oleh perusahaan yang ada di Provinsi Jambi sehingga menimbulkan kabut asap yang menjadi tebal. Hal ini dapat dikatakan demikian karena kabut as ap tidak hanya terjadi pada tahun 2019 saja, pada tahun sebelumnya juga pernah terjadi di tahun 2018, akan tetapi masih banyak perusahaan-perusahaan yang berani melakukan pembakaran hutan dengan alasan menghemat biaya anggaran yang dikeluarkan oleh perusahaan dalam membuka lahan.

Sementara itu, mengingat bahaya yang timbul dari kabut asap akibat kebakaran hutan tersebut maka sudah seharusnya pemerintah dan penegak hukum harus bersikap tegas terhadap perusahaan atau korporasi supaya tidak melakukan pembakaran hutan kembali sehingga tidak terjadi lagi kabut asap di Provinsi Jambi. Namun, pada kenyataannya pemerintah Provinsi Jambi dan penegak hukum masih banyak mempertimbangkan untuk perusahaan atau korporasi dalam menjatuhkan sanksi hukum. Tidak hanya itu saja, di dalam penegakan hukum juga masih terdapat tebang pilih terhadap pelaku pembakaran hutan sehingga terhadap pelaku pembakaran hutan yang dilakukan oleh perusahaan atau korporasi tidak dijerat sanksi pidana, akan tetapi yang dijerat dengan sanksi pidana justru orang yang melakukan pembakaran untuk membuka lahan kebun. Hal yang demikian sangat disayangkan 
karena hukum hanya dijerat terhadap pelaku yang lemah saja, jika pelaku yang kuat seperti perusahaan atau korporasi malah dibiarkan saja tindakannya melakukan pembakaran hutan seharusnya perusahaan-perusahaan yang telah melakukan pembakaran hutan tersebut sudah dapat dipertanggungjawabkan baik secara administrasi, perdata maupun pidana.

Selain itu juga, penegak hukum sulit untuk mencari siapa pelaku dalam pembakaran hutan tersebut, apakah memang benar kebakaran hutan tersebut dilakukan oleh perusahaan atau orang perorangan dalam membuka lahan. Untuk itu, sampai saat ini pihak Kepolisian yaitu Polda Jambi terus melakukan pengusutan terhadap kasus kebakaran hutan sehingga memerlukan waktu yang cukup lama. Akibat waktu pengungkapan yang cukup lama itu, kasus terkait dengan tindak pidana pembakaran hutan akan hilang begitu saja dengan alasan sulit untuk mengungkapkan pelaku pembakaran hutan tersebut sehingga terhadap pelaku pembakaran hutan tidak dapat dipertanggungjawabkan secara pidana.

Dengan adanya permasalahan lamanya waktu pengusutan tersebut sudah seharusnya terkait dengan pembuktian harus dilakukan penyederhanaan dalam hal alat bukti. Adapun isi Pasal 96 Undang-Undang Nomor 32 Tahun 2009 Tentang Perlindungan Dan Pengelolaan Lingkungan Hidup yaitu alat bukti yang sah dalam tuntutan tindak pidana lingkungan hidup terdiri atas:

a. Keterangan saksi.

b. Keterangan ahli.

c. Surat.

d. Petunjuk.

e. Keterangan terdakwa; dan/atau

f. Alat bukti lain, termasuk alat bukti yang diatur dalam peraturan perundangundangan.

Apabila dilihat dari isi Pasal 96 Undang-Undang Nomor 32 Tahun 2009 Tentang Perlindungan Dan Pengelolaan Lingkungan Hidup di atas maka dapat disimpulkan bahwa alat bukti yang harus dipenuhi oleh kepolisian terlalu banyak untuk mengungkapkan tindak pidana kebakaran hutan. Untuk itu, harus dilakukan penyederhanaan alat bukti terkait dengan pembuktian seperti hanya menggunakan keterangansaksi, petunjukdan keteranganterdakwa sehingga tidak membutuhkan waktu yang lama dalam mengungkapkan tindak pidana pembakaran hutan di Provinsi Jambi. 
Kemudian menurut Soerjono Soekanto, gangguan terhadap penegakan hukum yang berasal dari undang-undang mungkin disebabkan, karena $:^{13}$

1. Tidak diikutinya asas-asas berlakunya undang-undang.

2. Belum adanya peraturan pelaksanaan yang sangat dibutuhkan untuk menerapkan undang-undang.

3. Ketidakjelasan arti kata-kata di dalam undang-undang yang mengakibatkan kesimpangsiuran di dalam penafsiran serta penerapannya.

Apabila dilihat dari Undang-Undang Nomor 32 Tahun 2009 Tentang Perlindungan Dan Pengelolaan Lingkungan Hidup maka asas yang digunakan dalam Undang-Undang tersebut sudah jelas bahwa perlindungan dan pengelolaan lingkungan hidup dilaksanakan berdasarkan asas:

a. Tanggungjawab negara.

b. Kelestariandan keberlanjutan.

c. Keserasian dan keseimbangan;

d. Keterpaduan.

e. Manfaat.

f. Kehati-hatian.

g. Keadilan.

h. Ekoregion.

i. Keanekaragaman hayati.

j. Pencemar membayar.

k. Partisipatif.

1. Kearifanlocal.

m. Tata kelola pemerintahan yang baik,dan

n. Otonomi daerah.

Tidak hanya itu saja, setiap kalimat dalam Undang-Undang Nomor 32 Tahun 2009 Tentang Perlindungan Dan Pengelolaan Lingkungan Hidup sudah jelas kata-katanya sehingga sudah seharusnya terhadap pelaku tindak pidana kebakaran hutan tersebut harus dipertanggungjawabkan pidana. Hal demikian dapat dibenarkan karena di dalam UndangUndang Nomor 32 Tahun 2009 Tentang Perlindungan Dan Pengelolaan Lingkungan Hidup telah diatur sanksi pidana terhadap pelaku pembakaran hutan mulai dari Pasal 97 sampai

${ }^{13}$ Soerjono Soekanto, Faktor-Faktor Yang Mempengaruhi Penegakan Hukum, Cetakan Ke-11, Jakarta : Rajawali Pers, 2012, hal 17. 
dengan Pasal 120, dimana salah satu Pasal dalam Undang-Undang Nomor 32 Tahun 2009 Tentang Perlindungan Dan Pengelolaan Lingkungan Hidup tersebut telah tercantum sanksi pidana terhadap pelaku pembakaran hutan dan lahan. Salah satu Pasal tersebut yaitu Pasal 108 yang menjelaskan bahwa setiap orang yang melakukan pembakaran lahan sebagaimana dimaksud dalam Pasal 69 ayat (1) huruf h dipidana dengan pidana penjara paling singkat 3 (tiga) tahun dan paling lama 10 (sepuluh) tahun dan denda paling sedikit Rp. 3.000.000.000,00 (tiga miliar rupiah) dan paling banyak Rp. 10.000.000.000,00 (sepuluh miliar rupiah).

Namun, jika dilihat dari sifat pidana pembakaran hutan di atas masih bersifat materiil, seharusnya bersifat formil dan di dalam Undang-Undang Nomor 32 Tahun 2009 Tentang Perlindungan Dan Pengelolaan Lingkungan Hidup juga harus memberikan pidana percobaan dalam hal tindak pidana pembakaran hutan karena dengan adanya percobaan tersebut perbuatan itu sudah dikatakan sebagai tindak pidana. Sebab apabila tidak dicantumkan pidana percobaan dalam aturan hukum tersebut maka jika dilapangan terdapat orang yang telah membawa bensin dan korek api untuk membakar hutan, perbuatan tersebut belum dikatakan tindak pidana pembakaran hutan.

Kemudian dilihat dari sanksi pidananya juga maka masih dirasakan ringan apabila dijerat terhadap pelaku tindak pidana pembakaran hutan khususnya terhadap perusahaan atau korporasi. Seharusnya dijarat sanksi pidana berat terhadap pelaku tindak pidana pembakaran hutan karena mengingat akibat yang ditimbulkan dari pembakaran hutan tersebut banyak mengalami kerugian. Kerugian itu tidak hanya manusia saja, melainkan flora dan fauna serta perekonomian nasional juga ikut terganggu akibat dari pembakaran hutan tersebut. Selain itu juga, akibat dari pembakaran hutan tersebut Indonesia mendapatkan ancaman dari negara lain dikarenakan ekspor asap akibat pembakaran hutan di Indonesia itu masuk ke negara lain.

Tidak hanya itu saja, apabila dilihat dari kasus yang telah terjadi sebelum tahun 2019 terkait dengan kebakaran hutan dan lahan, kebanyakan pemerintah Provinsi Jambi dan penegak hukum masih seolah melindungi/ tidak dapat bertindak tegas para pelaku pembakaran hutan khususnya korporasi atau perusahaan-perusahaan yang ada di Provinsi Jambi. Dengan adanya hal demikian maka cukup sulit untuk dipertanggungjawabkan secara pidana perusahaan-perusahaan yang ada di Provinsi Jambi terkait dengan tindak pidana pembakaran hutan di Provinsi Jambi. 


\section{Upaya Yang Akan DilakukanSehubungan Dengan Pertanggungjawaban Pidana Terhadap Pelaku Pembakaran Hutan Di Provinsi Jambi}

Dalam hal Pertanggungjawaban pidana terhadap pelaku pembakaran hutan di Provinsi Jambi sudah seharusnya ditegakkan oleh aparat penegak hukum terhadap pelaku tindak pidana pembakaran hutan di Provinsi Jambi sehingga menjadi shokterapi para pelaku tindak pidana tersebut baik perusahaan maupun orang perorangan tidak akan lagi melakukan pembakaran hutan di Provinsi Jambi. Namun, apabila Pemerintah Provinsi Jambi dan aparat penegak hukum masih melindungi pelaku pembakaran hutan tersebut baik korporasi atau perusahaan maupun orang perorangan maka sulit untuk dipertanggungjawabkan pidana terhadap pelaku pembakaran hutan tersebut.

Akibat dari sulitnya menjatuhkan sanksi pidana terhadap pelaku pembakaran hutan tersebut maka tidak mengherankan kedepannya akan lebih banyak lagi titik-titik pembakaran hutan yang terjadi di Provinsi Jambi seperti tanggal 11 September 2019 berdasarkan data Badan Meteorologi Klimatologi dan Geofisika (BMKG) Stasiun Pekanbaru, pada pukul 06.00 WIB satelit Terra Aqua mendeteksi daerah paling banyak titik panas adalah Provinsi Jambi dengan 496 titik, Sumatera Selatan 305 titik dan Provinsi Riau ada 258 titik panas. ${ }^{14}$

Dapatlah dibayangkan apabila pertanggungjawaban pidana ini tidakdapatmenjerat terhadap pelaku pembakaran hutan maka akan meningkat terjadinya pembakaran hutan di Provinsi Jambi.Oleh karena itu, sudah seharusnya baik pemerintah Provinsi Jambi maupun aparat penegak hukum bertindak tegas terhadap pelaku pembakaran hutan untuk menjatuhkan sanksi pidana karena merupakan pertanggungjawaban atas perbuatan pelaku dalam melakukan pembakaran hutan dan lahan.

Selain menjatuhkan sanksi pidana terhadap pelaku pembakaran hutan atas dasar pertanggungjawaban pidana, pemerintah Provinsi Jambi maupun aparat penegak hukum Provinsi Jambi juga harus melakukan penyuluhan hukum terhadap korporasi atau perusahaanperusahaan dan masyarakat Provinsi Jambi sehingga perusahaan-perusahaan dan masyarakat Provinsi Jambi lebih mengetahui bahwa apabila melakukan pembakaran hutan dan lahan, ada sanksi pidana yang diatur dalam Undang-Undang Nomor 32 Tahun 2009 Tentang Perlindungan Dan Pengelolaan Lingkungan Hidup.

Terkait dengan penyuluhan hukum, dalam hal ini penyuluhan hukum sebaiknya digunakan secara langsung. Adapun yang dimaksud dengan penyuluhan hukum langsung

\footnotetext{
${ }^{14} \mathrm{https}$ ///bisnis.tempo.co/read/1246487/sumatera-dikepung-1-211-titik-panas-jambi-palingbanyak/full\&view=ok, diakses tanggal 29 September 2019.
} 
menurut Abintoro Prakoso adalah kegiatan penyuluhan hukum yang dilakukan secara langsung yakni penyuluhan hukum berhadapan dengan masyarakat yang disuluh, dapat berdialog dan bersambung rasa, misalnya ceramah, diskusi, sarasehan, temu wicara, peragaan, simulasi dan lain sebagainya. ${ }^{15}$ Jadi, apabila dilihat dari penjelasan Abintoro Prakoso mengenai penyuluhan hukum langsung, maka dalam hal ini penyuluhan hukum secara langsung dilakukan dengan cara ceramah terkait dengan isi Undang-Undang Nomor 32 Tahun 2009 Tentang Perlindungan Dan Pengelolaan Lingkungan Hidup dan diskusi karena lebih cepat mencapai sasaran untuk pencegahan terjadinya kebakaran hutan dan lahan.

Tidak hanya itu saja, terkait dengan pencegahan terjadinya kebakaran hutan maka harus melibatkan masyarakat setempat untuk melaporkan apabila ada pelaku pembakaran hutan yang ingin melakukan pembakaran hutan di daerah tersebut. Kerjasama antara masyarakat setempat dan aparat penegak hukum akan mengurangi tingkat kebakaran hutan yang yang telah terjadi di Provinsi Jambi. Strategi seperti ini harus dipertahankan demi mewujudkan lingkungan yang bersih dari kabut asap dan terpelihara keasliannya dari kebakaran yang biasanya dilakukan oleh korporasi atau perusahaan dan orang perorangan.

Selain itu juga, isi sanksi pidana dalam Undang-Undang Nomor 32 Tahun 2009 Tentang Perlindungan Dan Pengelolaan Lingkungan Hidup harus lebih diperberat lagi untuk memberikan efek jera terhadap pelaku pembakaran hutan di Provinsi Jambi. Hal yang senada juga diutarakan oleh Mukadir Iskandar Syah bahwa tujuan idealnya pelaku akan menyadari atas perbuatan yang lalu dan tidak akan mengulangi lagi serta sekaligus memberikan pelajaran kepada khalayak, untuk tidak melakukan perbuatan melawan hukum. ${ }^{16}$ Untuk itu, sudah seharusnya sanksi pidana yang terdapat di dalam Undang-Undang Nomor 32 Tahun 2009 Tentang Perlindungan Dan Pengelolaan Lingkungan Hidup harus diperberat lagi sehingga bagi pelaku pembakaran hutan tidak mengulangi perbuatannya lagi dan memberikan pelajaran terhadap masyarakat umum supaya tidak membuka lahan dengan cara membakar.

Sebenarnya penjatuhan sanksi pidana yang lebih berat tidak hanya memberi efek jera dan menakut-nakuti masyarakat secara umum, dengan adanya sanksi pidana yang begitu berat maka diharapkan dapat mencegah terjadinya pembakaran hutan untuk yang akan datang.Mengenai hal inisebagaimanajuga dikemukakan oleh Hans Kelsen bahwa sanksi dalam hukum pidana tujuannya adalah retributif atau menurut pandangan modern adalah

\footnotetext{
${ }^{15}$ Abintoro Prakoso, Sosiologi Hukum, Cetakan Pertama, Yogyakarta : Laksbang Pressindo, 2017, hal 184.

${ }^{16}$ Mukadir Iskandar Syah, Ilmu Hukum Dan Kemasyarakatan, Cetakan Pertama, Jakarta : Tatanusa, 2017, hal 93 .
} 
adanya pencegahan. ${ }^{17}$ Dengan demikian, apabila sanksi pidana yang diberikan terhadap pelaku pembakaran hutan maka akan mencegah terjadinya peningkatan terkait pembakaran hutan di Provinsi Jambi dan mencegah agar kedepannya tidak terjadi lagi kebakaran hutan di Provinsi Jambi.

Sementara itu juga, sanksi pemberatan yang diberikan terhadap pelaku pembakaran hutan selain sebagai pertanggungjawaban pidana, perbuatan pembakaran hutan tersebut juga telah merugikan banyak pihak, bahwa tidak menutup kemungkinan banyakanak-anak akan terserangsakit yang dapatmengakibatkankematian apabila kabut asap terus tebal menyelimuti Provinsi Jambi. Sedangkan kabut asap yang terjadi sekarang ini saja sudah mengakibatkan anak-anak libur sekolah. Akhhirnya proses pendidikan tidak berjalan sebagaimana mestinya dan aktivitas kantor juga tidak berjalan dengan baik dalam melayani masyarakat Provinsi Jambi. Selain itu pula, perlu direvisi Undang-Undang No 18 tahun 2013 dengan memasukan sanksi pidana pada undang-undang tersebut, karena sudah seyogyanya peraturan yang lebih khusus ini mempunyai ketentuan pidana, bukan hanya bersifat mengatur saja, namun harus memaksa dengan ketentuan sanksi. Hal lain yang mesti diperhatikan pula kedepannya adalah menyederhan akan alat bukti khusus untuk Tindak Pidana Pembakaran hutan dan lahan sehingga dapat lebih efisien dan efektif dalam memproses perkara ini, seperti contohnya penyederhanaan dalam alat bukti pada tindak pidana penghapusan kekerasan dalam keluarga, dengan demikian kekhususan Undang-Undang No 18 tahun 2013 Tentang Larangan Pembakaran Hutan dan Lahan akan menjadikan aturan ini sebagai alat yang ampuh menjerat pelaku tindak pidana pembakaran hutan dan lahan.

\section{E. Kesimpulan}

1. Pertanggungjawaban pidana terhadap pelaku pembakaran hutan di Provinsi Jambi adalah hanya berupa penyegelan di PT. Alam Bukit Tiga Puluh (ABT) dan belum dijatuhkan sanksi pidana, hanya berupa penyegelan terhadap perusahaan tersebut.

2. Faktor yang mempengaruhi terwujudnya pertanggungjawaban pidana pelaku pembakaran hutan di Provinsi Jambi adalah belum ada ketegasan baik dari pemerintah Provinsi Jambi maupun aparat penegak hukum untuk menjatuhkan sanksi pidana sesuai dengan konsep Pertanggungjawaban pidana, bahkan kebanyakan Pemerintah Provinsi Jambi dan penegak hukum masih seolah melindungi / tidak

17 Jimly Asshiddiqi dan M. Ali Safa'at, Teori Hans Kelsen Tentang Hukum, Cetakan Ketiga, Jakarta : Konstitusi Pres, 2012, hal 46. 
tegas terhadap para pelaku pembakaran hutan khususnya korporasi atau perusahaanperusahaan yang ada di Provinsi Jambi, kemudian dalam pembuktian masih banyak alat bukti dan di dalam undang-undang tersebut juga tidak ada diatur tindak pidana percobaan serta sanksi pidananya masih dirasakan ringan.

3. Upaya yang akan datang terkait dengan pertanggungjawaban pidana terhadap pelaku pembakaran hutan di Provinsi Jambi adalah pemerintah Provinsi Jambi maupun aparat penegak hukum bertindak tegas terhadap pelaku pembakaran hutan untuk menjatuhkan sanksi pidana, melakukan penyuluhan hukum terhadap masyarakat dan melibatkan masyarakat setempat untuk melaporkan apabila ada pelaku pembakaran hutan dan sanksi pidana dalam Undang-Undang Nomor 32 Tahun 2009 Tentang Perlindungan Dan Pengelolaan Lingkungan Hidup harus lebih diperberat lagi. Serta merevisi Undang-Undang No 18 tahun 2013 tentang Larangan Pembakaran Hutan dan Lahan

\section{F. Rekomendasi}

1. Kepada Pemerintah Provinsi Jambi dan aparat penegak hukum harus menuntaskan tindak pidana kebakaran hutan tersebut sehingga sanksi pidana dalam UndangUndang Nomor 32 Tahun 2009 Tentang Perlindungan Dan Pengelolaan Lingkungan Hidup dapat diterapkan.

2. Kepada pemerintah harus melakukan perbaikan dan mencantumkan terkait dengan penyederhanaan alat bukti, tindak pidana percobaan dan sanksi pidana berat di dalam Undang-Undang Nomor 32 Tahun 2009 Tentang Perlindungan Dan Pengelolaan Lingkungan Hidup, maupun terhadap Undang-Undang18 tahun 2013 tentang Larangan Pembakaran hutan dan Lahan.

3. Kepada Masyarakat Provinsi Jambi harus turut serta menjaga lingkungan sekitarnya dan melaporkan kepada aparat penegak hukum terkait adanya pelaku kebakaran hutan.

\section{G. DAFTAR PUSTAKA}

Abintoro Prakoso, Sosiologi Hukum, Cetakan Pertama, Yogyakarta : Laksbang Pressindo, 2017.

C. Djisman Samosir, Penologi Dan Pemasyarakatan, Cetakan Pertama, Bandung : Nuansa Aulia, 2016. 
Harumiati Natadimaja, Hukum Perdata Mengenai Hukum Orang Dan Hukum Benda, Cetakan Kedua, Yogyakarta : Graha Ilmu, 2009.

Jimly Asshiddiqi dan M. Ali Safa'at, Teori Hans Kelsen Tentang Hukum, Cetakan Ketiga, Jakarta : Konstitusi Pres, 2012.

Mukadir Iskandar Syah, Ilmu Hukum Dan Kemasyarakatan, Cetakan Pertama, Jakarta : Tatanusa, 2017.

RoniWiyanto, Asas-Asas Hukum Pidana Indonesia, Cetakan Pertama, Bandung : CV. Mandar Maju Pers, 2012.

Soerjono Soekanto, Faktor-Faktor Yang Mempengaruhi Penegakan Hukum, Cetakan Ke-11, Jakarta : Rajawali Pers, 2012.

Suhandi Cahaya, Kejahatan korporasi, Cetakan Pertama, Jakarta: Law Office, 2013. 